\title{
Social Dimension of Sustainable Housing Evaluation of Flats in Surabaya and Semarang
}

\author{
Annisa Nur Ramadhani, Dewi Septanti, Rika Kisnarini, Wahyu Setiawan, Adinda SPU \\ Architecture Department, Sepuluh Nopember Institute of Technology Surabaya \\ Indonesia
}

\begin{abstract}
Urban renewal can be seen in three spheres: as a process, as a function and as a program. Urban renewal process is defined as the built area re-development process to improve city's productivity, one of them is urban housing renewal. Sustainable urban housing renewal has a great opportunity to support economic development, environmental management and service, social and life equality. The construction of flats in the framework of urban housing renewal have the aim to improve the vitality and quality of the housing environment. Flats are urban housing renewal by means of redevelopment, which is rebuilding the city area by doing the demolition of some or entire urban areas that can not be maintained anymore. But in facts, there are many flats building that suffered from environment degradation and needs to be evaluated. Therefore, this research aims to give post occupation evaluation in the context of social dimension. The study case are coastal area flats in Surabaya and Semarang that were built with urban renewal program. This POE (Post Occupational Evaluation) will be necessary to conduct periodic evaluation of flat's residents occupancy in the context of urban renewal that needs to be done.
\end{abstract}

\section{INTRODUCTION}

Many cities in developing countries have encounter serious problems about coastal slums. In addition to environmental issues, communities also need to continue their livelihoods with activities that can support their daily needs (Septanti, D, 2015). Therefore, the improvement that leads to urban renewal, should consider the residents resettlement to locations that are not so far from their original location (UNHabitat, 2003). This means that housing for low-income communities should adapt to climatic, weather and geographic conditions of coastal areas.

To improve the quality of settlements in coastal areas, it is necessary to have an urban renewal program. Although difficult to measure, urban renewal could bring improvements to areas that suffered from environmental degradation (Sihono, 2003). Urban renewal is known as the rejuvenation of urban built areas that attempt to rearrange certain areas with to obtain added value while maintaining the function and quality of the environment (Danisworo, 1988). Urban renewal is one efforts to build decent dwellings for all parties through sustainable settlement mission. Thus, Indonesian government have provides a policy to implement the rearrangement of slum areas by not relocating the local residents, but replacing and rearranging the original area to improve the environmental, social and economic quality of the local community.
The construction of flats in urban housing renewal framework have the aim to improve the vitality and quality of the housing environment. Flats are urban housing renewal by means of redevelopment, which is rebuilding the city area by doing demolition of some or entire city areas that can not be maintained anymore (Act No. 24 / Year 1992).

But specifically, if newly constructed housing is not designed with efficiency and sustainability consideration, the development process will only become a new burden for the environment and climate, as it will only be an act of economic waste and social ugliness. In addition, if large-scale housing renewal are conducted without regard to sustainable setlements principles, the results will not be able to reduce the environmental footprint of existing housing (UNHABITAT, 2012).

Sustainable housing has a great opportunity to support economic development, environmental stewardship, service, and social equality. On the other hand, sustainable housing can also reduce the risks of problems caused by population growth, urbanization, slums, poverty, climate change, lack of access to sustainable energy, and economic uncertainty (UNHABITAT, 2012).

This research aims to give Post Occupation Evaluation in the context of social aspects. The study case are flats in coastal areas in Indonesia that were built with urban renewal program. This POE (Post Occupational Evaluation) will be necessary to conduct periodic evaluation of occupancy to consider flats in the context of urban renewal that needs to be done.

\section{LITERATURE REVIEW}

\section{A. Urban Housing Renewal Process}

Urban design theory is an effort of planning and arrangement of space (Andy, 1997). Urban design includes the design preparation and regulatory frameworks, even laws to control development and overlap with urban planning. Urban design includes the design and structure of a particular space that overlaps with architecture, architectural landscape, road engineering and industrial design. Urban design theory also handles problems, guides and helps the use and maintenance of urban areas and public spaces.

In urban design theory, urban planning, land use planning and transportation planning are attempted to promote economic, environmental and social development. Urban design can include urban renewal by adapting urban planning 
methods to urban areas that suffer from urban decay and environmental degradation.

Urban renewal can be seen in three spheres: as a process, as a function and as a program (Sujarto, 1985: 2). Urban renewal process is defined as the re-development process of the built area to improve the productivity and usefulness of the city. As a function of urban renewal is defined as an activity to control, organize and rehabilitate or rebuild a part of the urban decay to accommodate activities consistent with the existing city plan. Therefore, urban renewal program can be a part of a coordinated and integrated city development activities.

The newly designed urban renewal should take into account the context of efficiency and sustainability for not becoming a new burden to the environment and climate. In addition, massive urban renewal without regard to sustainable principles will not be able to reduce the environmental footprint of the existing environment (UN-HABITAT, 2012). Sustainable urban renewal has a great opportunity to support economic development, environmental management and service, social and life equality. On the other hand, it can also reduce the risks of problems caused by population growth, urbanization, slums, poverty, climate change, lack of access to sustainable energy, and economic uncertainty (UNHABITAT, 2012). In achieving sustainable conditions, there are four dimensions to be considered, which are environmental, social, economic, and cultural. And in each dimension consists of three levels, namely: (1) the macro level covering the national scale; (2) meso levels covering regional or city scale; (3) micro level that is covering residential environment scale (UN-HABITAT, 2012). Detailed research conducted in the micro level (neighborhood).

\section{B. Social Dimension according to Sustainable Housing For Sustainable Cities (UN Habitat, 2011)}

According to Sustainable Housing for Sustainable Cities, a multi scale framework for sustainable housing policies are mention belows:

For Macro (National Levels):

1. Fulfilling the right to adequate housing and promoting the right to the city

2. Ensuring affordable, decent and suitable homes for all, including disadvantaged groups

3. Developing social housing provision

4. Promoting choice and security of tenure.

For Meso (City Levels):

1. Promoting integrated comunities and ensuring trust in communities

2. Providing community facilities, preventing segregation and displacement

3. Regenerating and reintegrating 'neglected' areas into regional, urban fabric

4. Ensuring infrastructural integration of housing into wider areas

5. Upgrading inadequate housing and slum areas.
For Micro (Neighborhood Levels):

1. Empowering people and ensuring public participation

2. Ensuring health, safety, well-being in residences

3. Creating a sense of community, 'sense of place', and identity

4. Meeting secific needs and wants in housing (including those related to gender, age and health). Providing access to infrastructure and public spaces

In this research context, the POE (Post Occupation Evaluation) methods will use micro levels as the measurement variable. Therefore, will be added with some indicators as mention below:

a.Empowering people and ensuring public participation
a. Planning Process
b. Development Process
c. Maintanance Process
d. Community Service

b. Meeting secific needs and wants in housing (including those related to gender, age and health). Providing access to infrastructure and public spaces
a. Kitchen
b. Toilets
c. Environmental Sanitation System
d. Weather Control System
e. Lighting System
f. Stairs
g. Parking Security

c.Creating a sense of community, 'sense of place', and identity
a. Length of Stays
b. Individual intention to move / stay
c. Reason if they want to move.
d. Enjoy to Stay
e. Social Bonding or Neighborhood

d. Ensuring health, safety, well-being in residences
a. Safety:
- Stealing Safety
- Violation Safety
- General Safety

b.Social Facilities Utilization and AccessibilityStealing Safety

- School

- Health Facility

- District Office

- Main Street

- Mosque

- Market

- Mall

\section{METHODS}

The research methods using Post Occupancy Evaluation (POE) method. POE generally involves various activities and processes systematically evaluating the performance of 
buildings occupied for some time (Preiser, 2002; Preiser et al., 1988). At the same time this type of research is descriptive, because it describes the characteristics of society, activities and homes they occupy. Thus the conclusions drawn by deductive reasoning are carried out using frequencies, averages etc. A mixed research method is applied that combines the analysis of quantitative and qualitative data collection and interpretation, including determining the quantitative spatial design attributes and qualitative user requirements. This method has improved the reliability and validity of the research findings, through triangulation of methods (Zeisel, 1984)). A field survey was used as a strategy to collect data on homes and households. A literature study was conducted to complete a method for collecting data on existing design standards.

This research will study and evaluate six flats (rusun) in Surabaya and Semarang. All of them is urban renewal flats and was built in varied year. Sombo flats and Dupak Flats was built in 1990s, whereas Romokalisari flats was built recently in 2010. Bandarharjo and Pekunden flats is the oldest flats in Semarang, that was built in 1990s. Whereas Kaligawe flats was built afterward in 2000s.

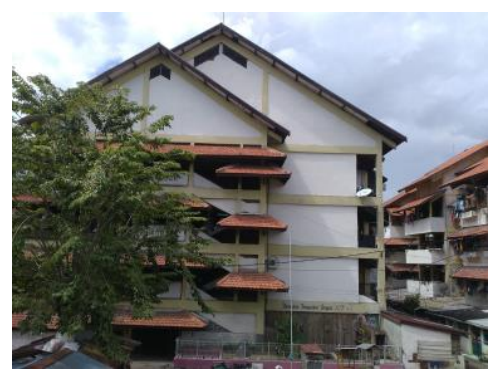

Fig.1. Rusun Sombo in Surabaya

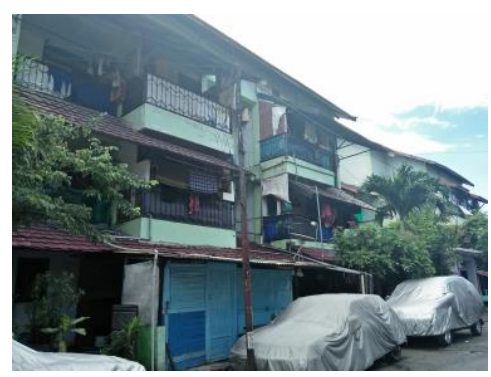

Fig.2. Rusun Dupak in Surabaya

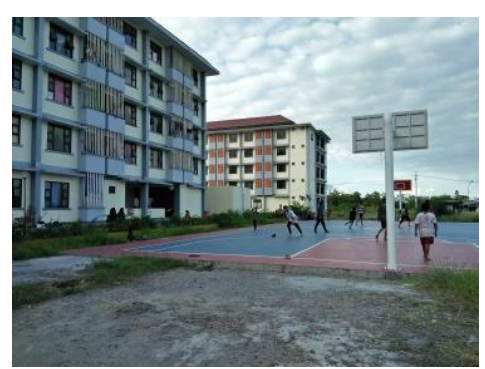

Fig.3. Rusun Romokalisari in Surabaya

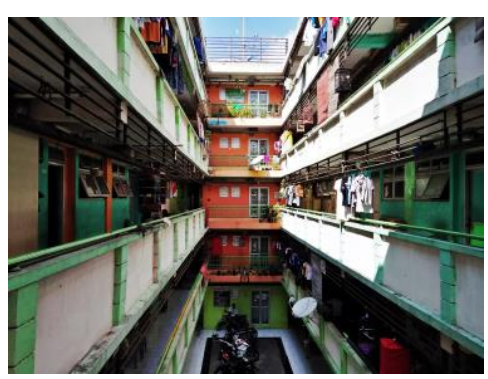

Fig.4. Rusun Kaligawe in Semarang

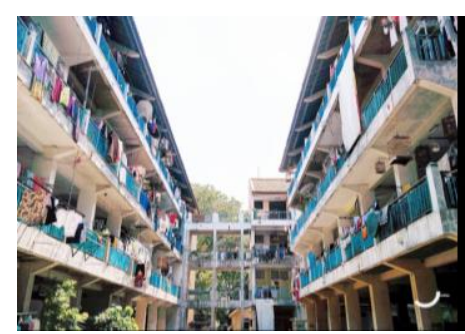

Fig.5. Rusun Pekunden in Semarang

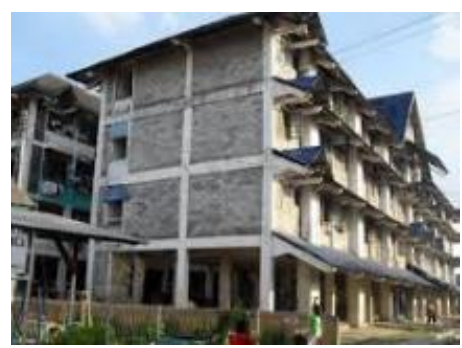

Fig.6. Rusun Bandarharjo in Semarang

\section{RESEARCH RESULTS}

In this research, the flat's POE (Post Occupation Evaluation) methods in Surabaya and Semarang will use indicators from social dimension micro level according to Sustainable Housing For Sustainable Cities (UN Habitat, 2011) as the measurement variable.

\section{Empowering people and ensuring public participation}

\section{a. Planning Process}

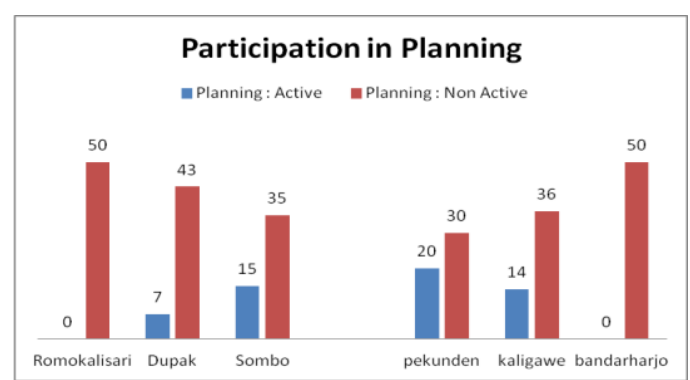

Fig.7. Participation in Planning Process

In planning process, most of the residents have not actively engaged. Only in few flats residents were involved, which are in Dupak, Sombo, Pekunden, and Kaligawe flats. This is because these four flats 
involved former residents to be participated in designing the flats concept.

\section{b. Development Process}

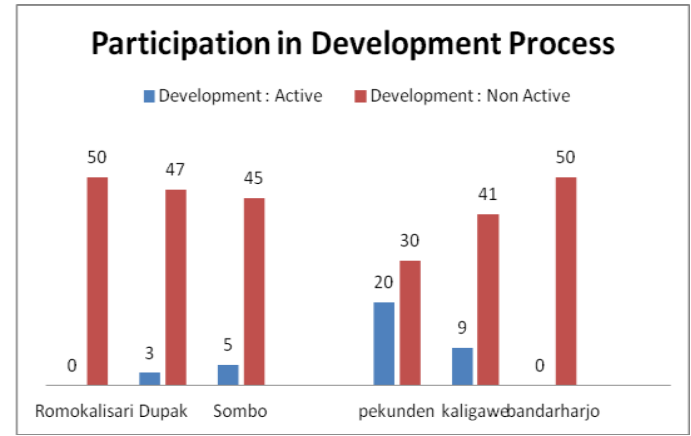

Fig.8. Participation in Development Process

It can be seen on the graph that flat's residents are not actively involved in the building and development process. This is because most of development process is carried out by private developer and managed by local government. Therefore, only in few cases its involve the residents such as in the Pekunden's flat.

\section{c. Maintanance Process}

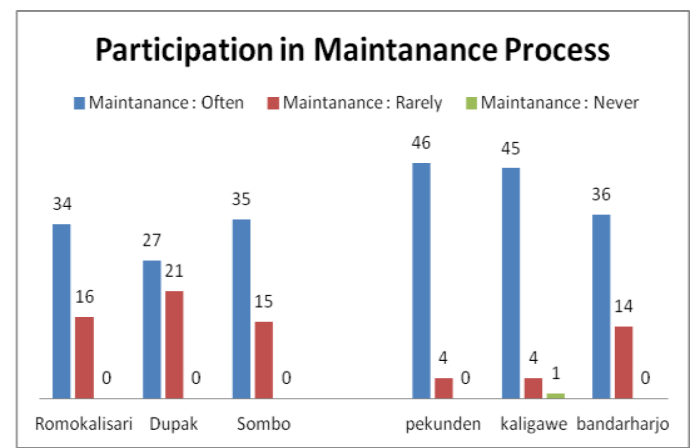

Fig.9. Participation in Maintanance Process

Contrary with the planning and building process, in the maintanance process residents are actively involved. This is because the residents have control over the maintenance of their flat, even though the routine maintenance still presence under the control of flat manager and government. The forms of participation in this maintanance process are varied, ranging from community service, environmental cleaning, painting walls and corridors, and also adding some public facilities such as prayer rooms and shared kitchens in their flats.

\section{d. Community Service}

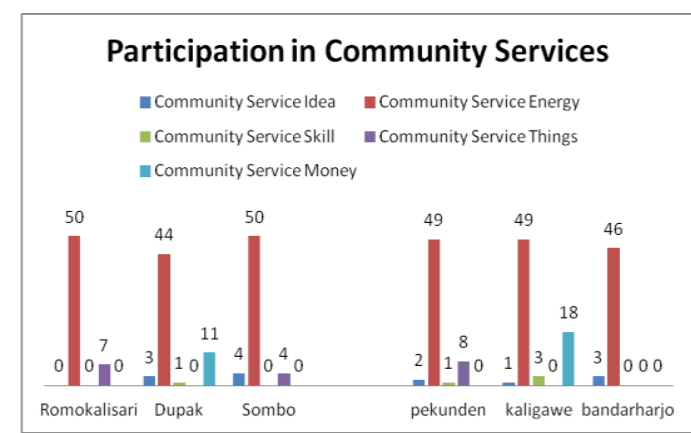

Fig.10. Participation in Community Services

In terms of community service, most of the residents do their social works by giving their energy, which is actively involved in environmental cleaning and maintenance activities. Some other people participate through giving cash and goods in the form of providing snacks and drinks for people who do social works.

2. Meeting specific needs and wants in housing (including those related to gender, age and health). Providing access to infrastructure and public spaces

\section{a. Kitchen}

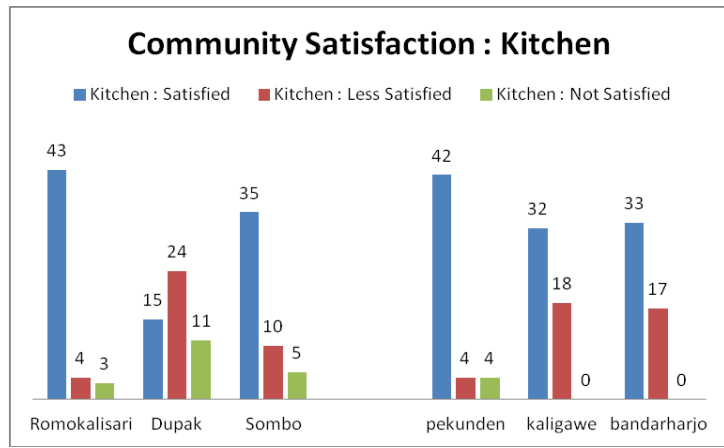

Fig.11. Community Satisfaction in Kitchen Facilities

From the graphic above it can be seen the residents satisfaction for their flat's kitchen facilities. The majority of people are satisfied with the condition of their kitchen. From six studied flats, there are two types of flats among them. One is flat with shared kitchen (outside the house unit) and another one is flat with kitchen inside the house unit. Sombo flat is a flat which has a shared kitchen outdoors, but many people choose to personalize their own with some addition of their private kitchen unit in front of their house (located along the corridor). This causing the narrowing corridor due to the addition of private kitchen. This also causing the shared kitchen space that has been built before has not been utilized properly (Figure 12 and 13). This case is different from other flats which have private kitchen units in their respective house units. 


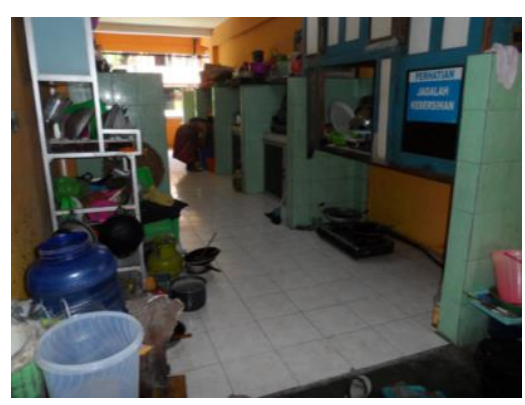

Fig.12. Shared Kitchen in Sombo Flats

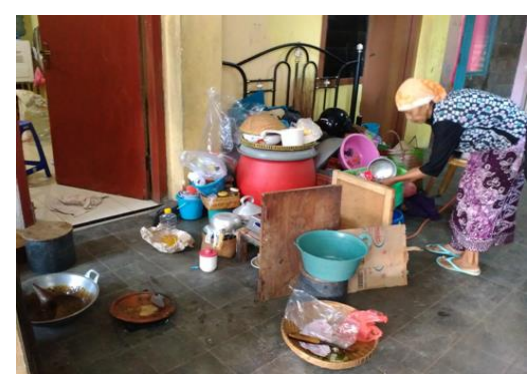

Fig.13. Resident's personalization of kitchen in the corridors

\section{b. Toilets}

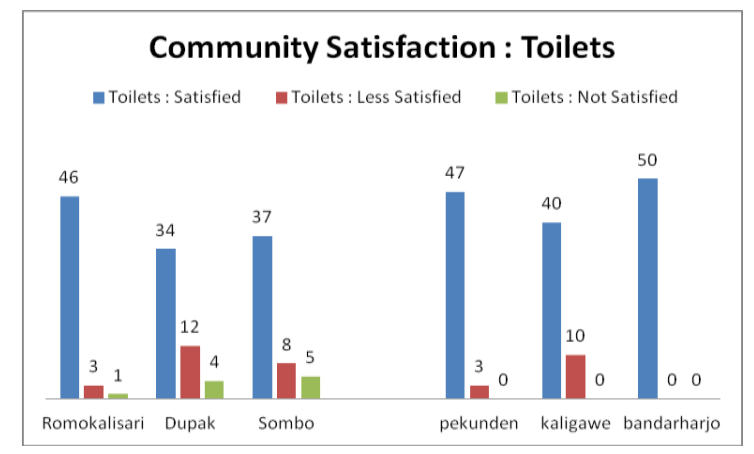

Fig.14. Community Satisfaction: Toiltes

For toilet conditions, most of the people are satisfied with the condition of their respective toilet facilities. There are two types of toilets in these flats, namely flats with shared toilet system (public toilets) and flats with private toilets that located inside each house unit. Shared toilets can be seen in sombo and dupak flats, where toilets are used communally for the residents in one corridor. Whereas for pekunden, kaligawe, bandarharjo and romokalisari have their private toilets in each house unit. c. Environmental System

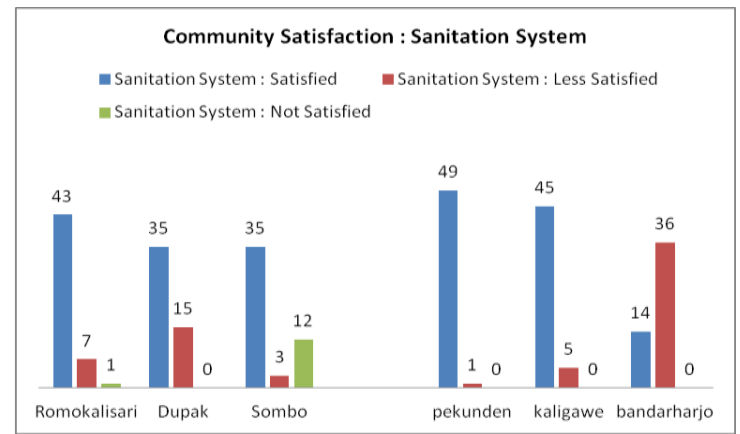

Fig.15. Community Satisfaction: Sanitation System

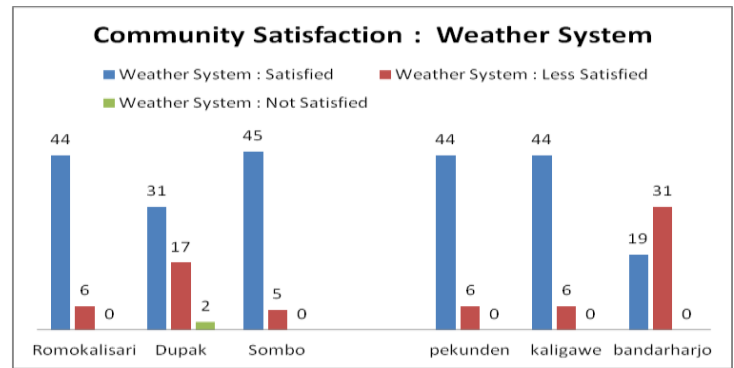

Fig.16. Community Satisfaction: Weather System

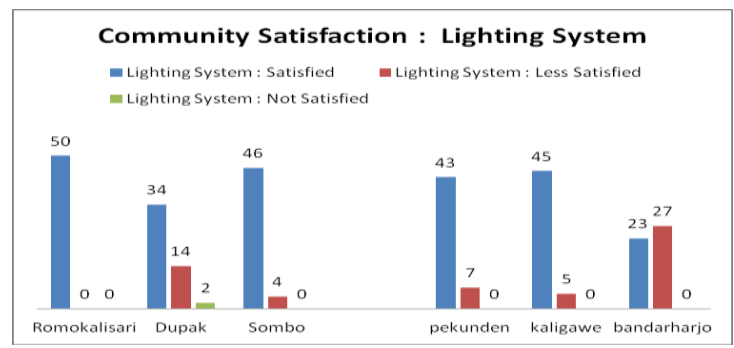

Fig.17. Community Satisfaction: Lighting System

The evaluation of the environmental system including sanitation systems, weather systems, and lighting systems, it can be seen that only Bandarharjo flats showed negative results (residents unsatisfactory). Other flats show positive results and indicate positive community satisfaction. This is because the condition of Bandarharjo flats is not well maintained. This matter also closely related to the social bonding conditions among residents in Bandarharjo flats which shows the lowest value compared to the other flats that have been studied. This indicates that there is a relationship between social bonding and the quality of environmental conditions. 

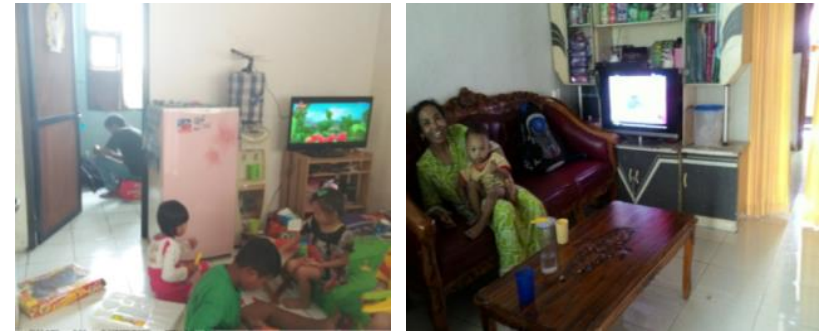

Fig.18. Room condition in Romokalisari flat (left) and Dupak flat (right)

\section{d. Stairs}

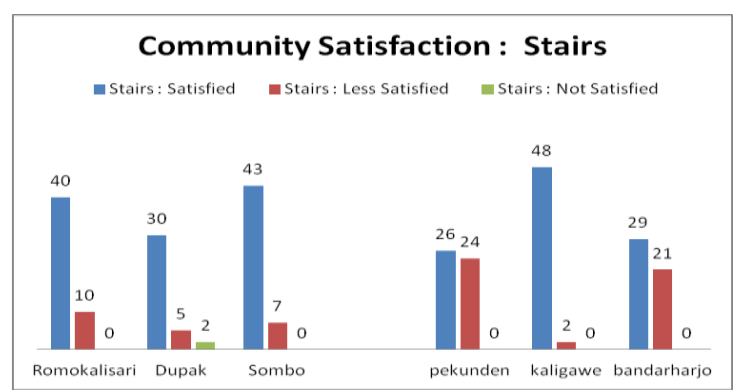

Fig.19. Community Satisfaction: Stairs

In terms of stairs condition, residents from all flats that have been studied agreed to provide a positive evaluation and feel satisfied. This is because the case studies are walk-up flat that has only maximum 5 floors. Therefore, the stairs still reachable for the residents. In addition, there are several policies and consideration in some flats that placing elderly people on the ground floor to facilitate their circulation.
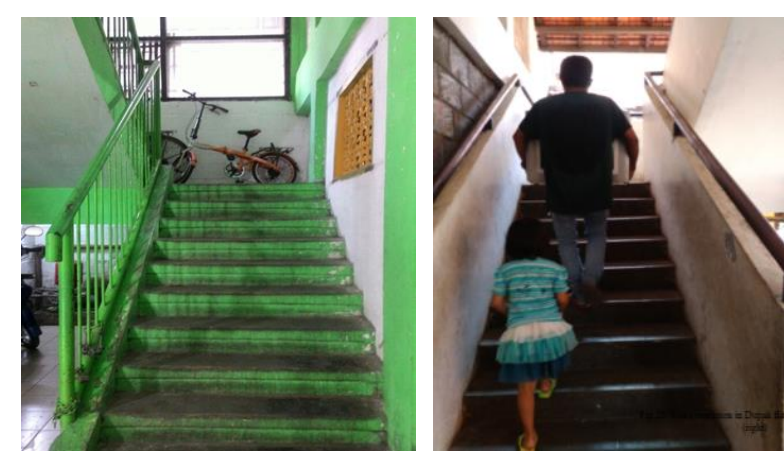

Fig.20. Stairs condition in Dupak flat (left) and Sombo flat (right)

\section{e. Parking Security}

For the security evaluation of the parking area, most of the residents claim that the flats are quite safe against theft. This is because there is a night patrol system by the flat's residents in turns to maintain environmental security.

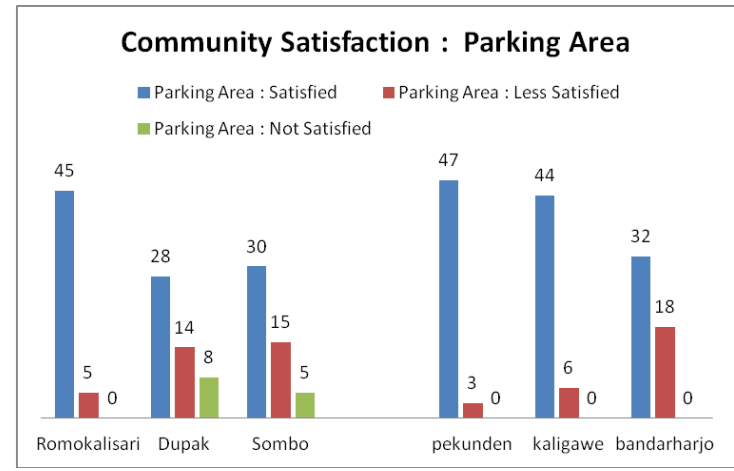

Fig.21. Community Satisfaction: Parking Area

3. Creating a sense of community, 'sense of place', and identity

a. Length of Stays

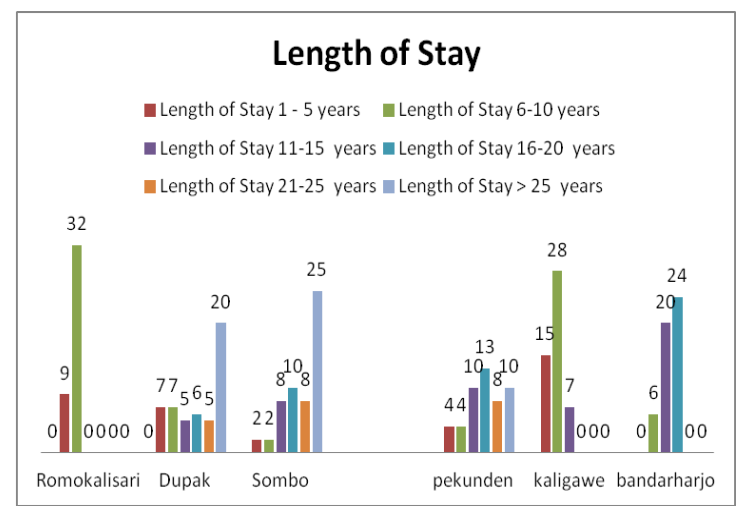

Fig.22. Length of Stay

From the graph data above, it can be seen that the flat with the majority of residents who have lived more than 25 years are Sombo and Dupak flats. This is because these two flats are the oldest flat that have been built in Surabaya and until now still utilized properly. As in Semarang, Bandarharjo flat has the highest number of people with the longest living time (16-20 years). This also because Bandarharjo flat is the oldest flat in Semarang, while the other two flats (Pekunden and Kaligawe) are newly built.

\section{b. Individual intention to move / stay}

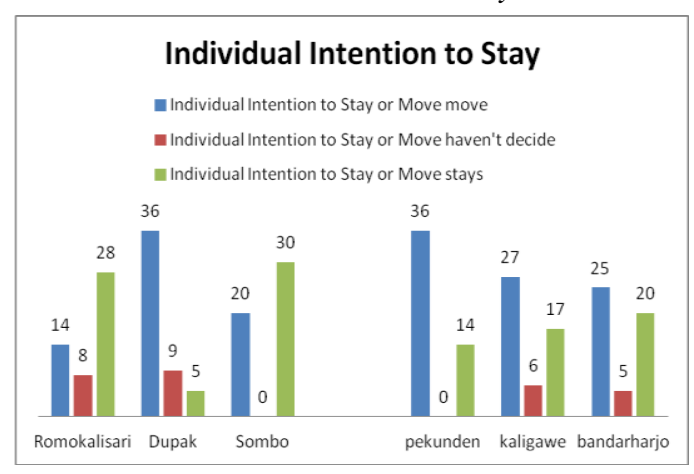

Fig.23. Individual Intention to Stay 
c. Reason if they want to move

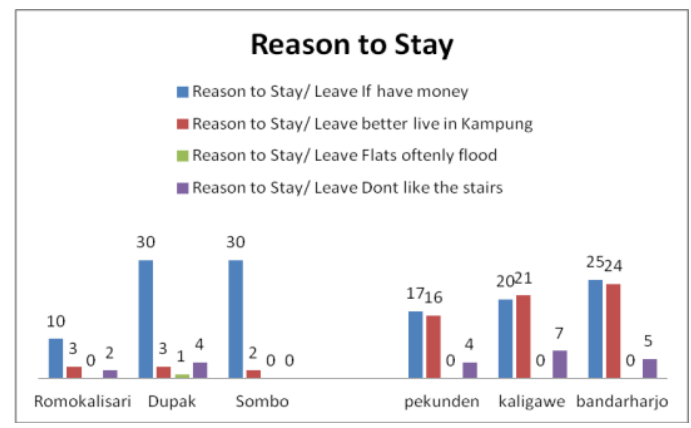

Fig.24. Reason to Stay

In terms of evaluation for individual intention to move or stay in flat, surprisingly the result indicates that the majority of residents from all flats want to move out from the flat to the ordinary house, except people from Sombo flats who still want to stay in. The resident's reasons for wanting to move out are various, starting from their desire to own a home and land assets, a desire to have a house with a garden, neighborhood reason, and some of them feels that flat's stairs is something borthersome. While people who still want to stay in the flat are mostly because they are not having enough money to buy their own house. Beside that, they prefer to stay in flat because of cheap rental cost (approximately only 2-4 dollars per month), like what happened in Sombo flats. In addition, neighborhood engagement and strong social bonding also have a great impact in determining their intention to live or move out from flat.

\section{d. Enjoy to Stay}

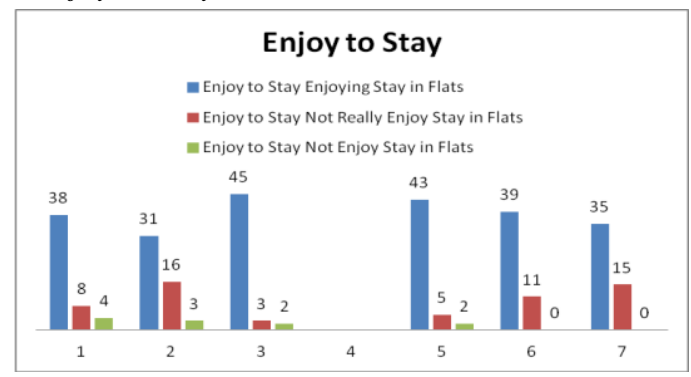

Fig.25. Enjoy to Stay

In terms of the evaluation wether residents enjoy to stay in flats or not, the majority of the residents claimed to enjoy it. Only a few of the community have their negative evaluation due to several reasons such as bad neighborhood engagement issues and their desire to have their own house assets. The highest percentage of resident's satisfaction obtained by Sombo flats in Surabaya and Pekunden flats in Semarang. This is closely related to the high social bonding level in these flats.

\section{e. Social Bonding or Neighborhood}

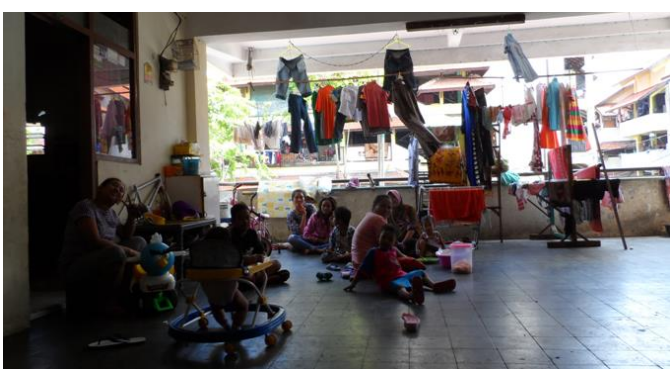

Fig.26. Corridors condition in Sombo's flat

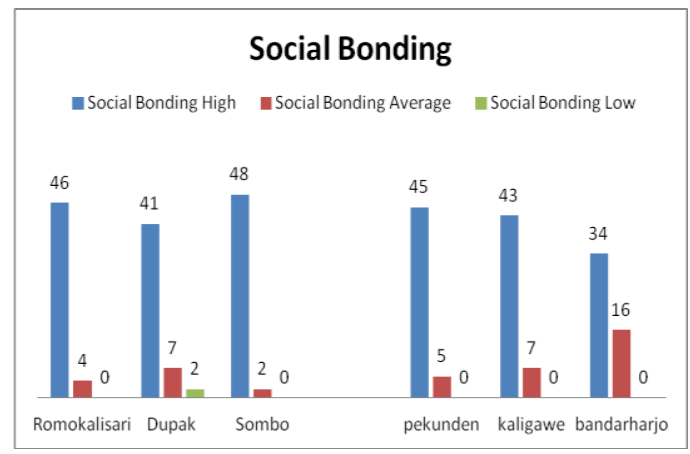

Fig.27. Social Bonding Condition

From the data above about social bonding evaluation, it can be seen that the majority of the residents from the studied flats have good social bonding levels. This is because almost of the flats are urban renewal flats that relocating the original inhabitants of the former kampung into newly built flat in the same location. With this background, residents have known each others well long before the flats was built. This also resulting in the high level of resident's social bonding that urban renewal flats have compared to non-urban renewal flats. In addition, routine public activities that are carried out by the community such as joint recitations, arisan, PKK, and neighborhood meetings have made social bonding ties between residents even stronger.

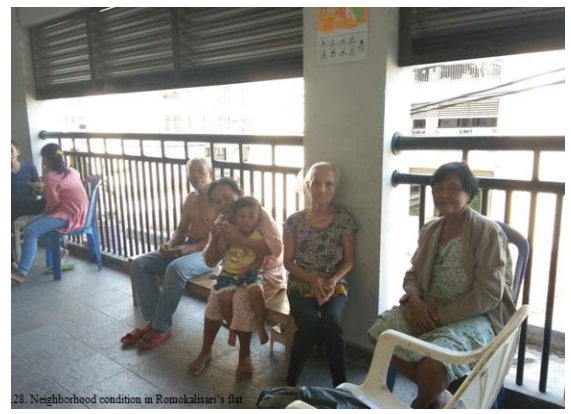

Fig.28. Neighborhood condition in Romokalisari’s flat 
4. Ensuring health, safety, well-being in residences a. Safety:

\section{- Stealing Safety}

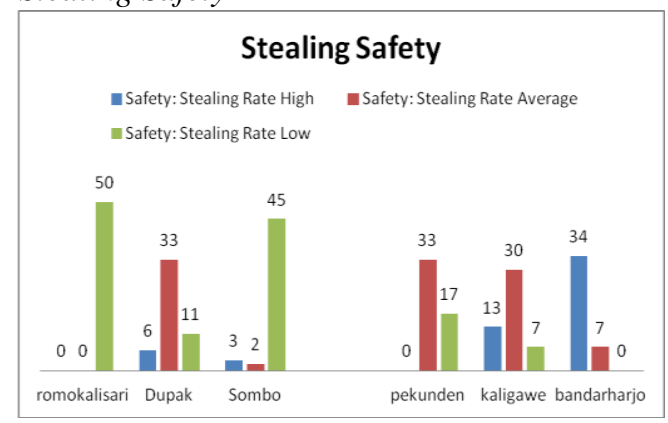

Fig.29. Community Satisfaction: Parking Area

\section{- General Safety}

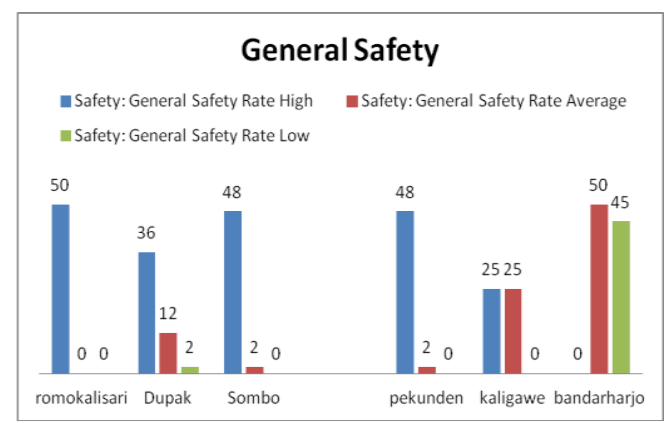

Fig.30. General Safety

From the data obtained, it can be seen that the public perception of stealing rate in Surabaya's flats is lower than in Semarang's flats. It can be seen in the graph that Sombo and Romokalisari flats have the lowest stealing rate compared to the other six flats. While the highest stealing rate is found in Bandarharjo that is located Semarang. Stealing security can also affect people's desire to move out from flats because it will be considered as less secure place to live.

\section{b.Social Facilities Utilization and AccessibilityStealing Safety}

- Public Space

- Mosque

- Corridors

- Balcony

- Parking Area

- School

- Health Care

- Main Street

- Market

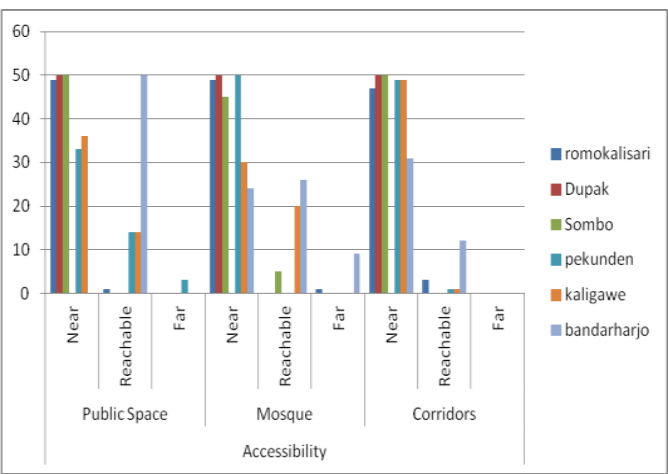

Fig.31. Accessibility Evaluation

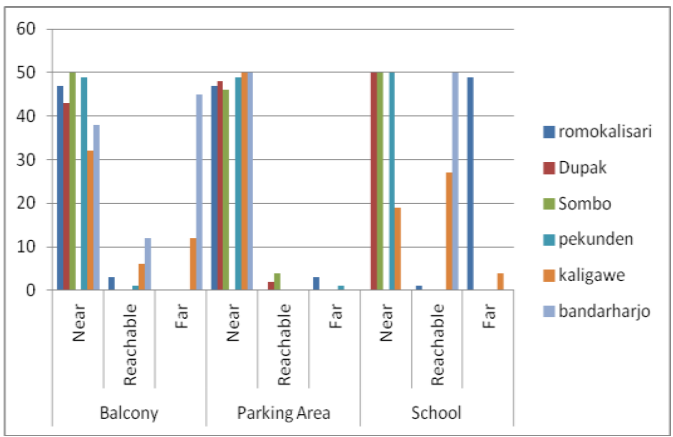

Fig.32. Accessibility Evaluation

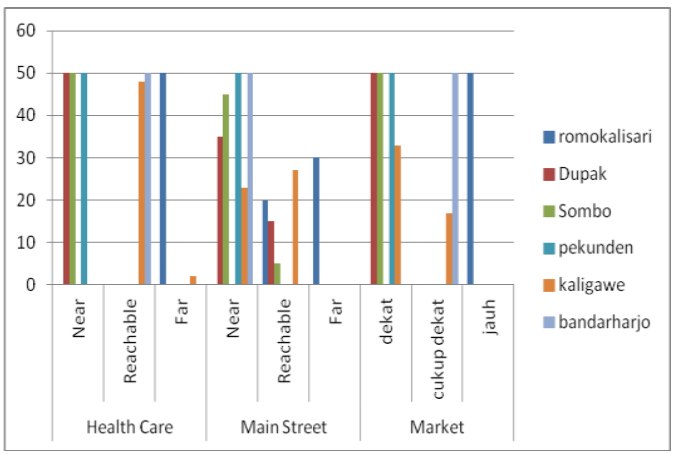

Fig.33. Accessibility Evaluation

It can be seen from the graph above about the flat's accessibility for public facilities such as markets, malls, main roads, mosques, and schools. Accessibility to public facilities becomes an important issues and main considerations for finding a good place to live. From the graphic can be seen that Pekunden flat's has the best accessibility to public facilities. This is because Pekunden flat is located in the city center of Semarang, making it easier for the residents to go to their daily destination such as workplace, school and marketplace. On the other hand, the flat that has the lowest accessibility among these six flats is Romokalisari. This is because the location of Romokalisari is quite isolated and far away from the main road. In addition, access to public transportation is quite difficult around the flats. Romokalisari flat is built on a new land environment near the sea (designated for fisherman's flat) and has not been surrounded by public facilities yet such as schools, markets, and malls. 


\section{CONCLUSION}

From the results of the previous discussion, it can be concluded that:

1. Social bonding and neighborhood relationship have an impact to resident's satisfaction

2. Residence should be given an understanding of the social interaction pattern and behaviour setting that is different from the previous kampung as an excess of changing the pattern from horizontal to the vertical dwelling. Because from the data it can be seen that most of the residents have intention to move and prefer to live horizontally like in kampung.

\section{ACKNOWLEDGEMENT}

The authors wish to thank Architecture ITS Department and DRPM DIKTI Indonesia for funding this research, as this paper is a part of research titled "Evaluation of Urban Renewal Flats in Coastal Area".

\section{REFERENCES}

[1] Danisworo, Mohamad, (1998), Konseptualisasi Gagasan dan Upaya Penanganan Proyek Peremajaan Kota: Pembangunan Kembali (Redevelopment) Sebagai Fokus, ITB, Bandung.

[2] Sihono, (2003). Peran Serta Masyarakat Dalam Pengelolaan Prasarana Pasca Peremajaan Lingkungan Permukiman Di Mojosongo Surakarta. Magister Perencanaan Pembangunan Wilayah dan Kota Universitas Deponegoro.

[3] Septanti, D (2015); Functionality and Adaptability of Coastal Low Income Houses in Java Indonesia; Technical University of Eindhoven (TU/e); Eindhoven, The Netherlands

[4] Sujarto. 1985. Beberapa Pengertian Perencanaan Fisik. Bharatara Karya aksara, Jakarta.

[5] Wolfgang F.E. Preiser, Ulrich Schramm, (2002) "Intelligent office building performance evaluation", Facilities, Vol. 20 Issue: 7/8, pp. $279-287$

[6] Zeisel. Inquiry by Design (2984). Edition, illustrated, reprint. Publisher, CUP Archive. ISBN, 0521319714, 9780521319713

[7] UN-Habitat. (2003), Slum of The World: The Face of Urban Poverty in The Millenium, United Nations of Human Settlements.

[8] UN-Habitat. (2011).

[9] UN-Habitat. (2012). Sustainable Housing For Sustainable Cities : A policy Framework For Developing Countries. Nairobi.

[10] UN. (2013 ). World Economic and Social Survey 2013, Sustainable Development Challenges (D. o. E. a. S. Affairs, Trans.) 